\title{
Genetyczne czynniki etiologiczne w zaburzeniach ze spektrum autyzmu (ASD)
}

\section{dr Sylwia Trambacz- Oleszak $^{\varpi}$,}

\section{lic. Tetiana Nosulia}

Instytut Biologii i Ewolucji Człowieka, Wydział Biologii, Uniwersytet im. Adama Mickiewicza w Poznaniu

https://doi.org/10.18388/pb.2021_377

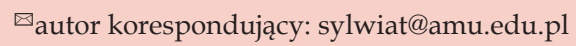

Słowa kluczowe: autyzm, ASD, czynniki genetyczne, mutacje genetyczne, modele dziedziczenia

\section{STRESZCZENIE}

Zaburzenia ze spektrum autyzmu (ang. autism spectrum disorder, ASD) stanowią dość powszechne wczesne zaburzenia neurorozwojowe charakteryzujące się zróżnicowanym przebiegiem i objawami. Wpływa to znacząco na stawianie diagnozy i przebieg terapii. $Z$ tego też powodu dużych możliwości diagnostycznych oraz terapeutycznych upatruje się $\mathbf{w}$ badaniach genetycznych. Celem niniejszej pracy poglądowej jest omówienie architektury genetycznej ASD oraz możliwych strategii terapeutycznych. Omówiono wzorce dziedziczenia ASD, wskazano wariancje genetyczne (m.in. polimorfizmy typu $\mathrm{CNV}$ ) oraz ukazano procent populacji osób z ASD z podziałem na poszczególne klasy mutacji genetycznych. Ukazano najważniejsze trzy podstawowe modele dziedziczenia: poligenowy, oligogenowy i genu głównego. Przedstawiono także mechanizmy molekularne i komórkowe połączone z modelami neurobiologicznymi związanymi z ASD. Badania genetyczne ewidentnie potwierdzają różnorodność genetycznych czynników odpowiedzialnych za występowanie ASD. Systemy modelowe oparte na genach zespołu neurorozwojowego wykazują zdolność do odwrócenia pewnych deficytów nawet u dorosłych pacjentów.

\section{WPROWADZENIE}

Zaburzenia ze spektrum autyzmu (ASD) są jednostką chorobową z grupy zaburzeń neurorozwojowych, zgodnie z przyjętą wykładnią Amerykańskiego Towarzystwa Psychiatrycznego i Światowej Organizacji Zdrowia [1,2] i mają swój początek we wczesnym dzieciństwie. ASD charakteryzują się trwałym deficytem w kontaktach oraz interakcjach społecznych, który uwidacznia się w różnorodnych sytuacjach, wliczając w to deficyty w relacjach interpersonalnych, komunikacji niewerbalnej oraz umiejętności do utworzenia, zrozumienia i podtrzymania więzi społecznych oraz relacji międzyludzkich [1]. Ponadto, w przypadku diagnozy zaburzeń ze spektrum autyzmu, istotne jest rozpoznanie powtarzalnych i/lub kompulsywnych wzorców zachowania, zainteresowań oraz aktywności [3]. Według Światowej Organizacji Zdrowia autyzm dotyka jedno dziecko na 160 urodzonych [2,4]. W ostatnim czasie można zaobserwować znaczący wzrost zachorowalności, który wynika nie tylko ze zwiększonej liczby zachorowań, ale także ze zwiększonej liczby rozpoznań tych zaburzeń.

Ogólnie przyjmuje się, iż rozmaite czynniki są zaangażowane w etiologię ASD: neurologiczne (zmiany w mózgu), środowiskowe (czynniki prenatalne, perinatalne i postnatalne) i biologiczne (czynniki genetyczne, infekcje, zaburzenia metaboliczne, czynniki immunologiczne, czynniki neurochemiczne oraz hormony i neuroprzekaźniki). Ze względu na to, że genetyczne czynniki etiologiczne stanowią istotną grupę w występowaniu zaburzeń ze spektrum autyzmu, obecnie szczególnie duży nacisk kładzie się właśnie na badania genetyczne, upatrując w nich sposobu na bardzo wczesną diagnozę i możliwą terapię. Celem niniejszej pracy jest, na podstawie obecnego stanu wiedzy, omówienie architektury genetycznej zaburzeń ze spektrum autyzmu oraz możliwych strategii terapeutycznych.

\section{GENETYCZNA ARCHITEKTURA ZABURZEŃ ZE SPEKTRUM AUTYZMU}

Stały rozwój badań genetycznych odnoszących się do mutacji genów oraz ich wpływu na różnorodne schorzenia dostarcza informacji dotyczących także zaburzeń ze spektrum autyzmu. Podstawowym elementem, który jest badany pod względem genetycznym jest dziedziczenie danej jednostki chorobowej. Etiologia zaburzeń ze spektrum autyzmu pod względem dziedziczenia opiera się na czterech podstawowych wzorcach dotyczących odpowiednio [5]:

- dziedziczenia autosomalnego recesywnego,

- dziedziczenia autosomalnego dominującego, 


\begin{tabular}{|c|c|c|}
\hline Dziedziczenie & Schemat & Zaburzenia \\
\hline $\begin{array}{l}\text { Autosomalne } \\
\text { recesywne }\end{array}$ & $\Longleftrightarrow$ & $\begin{array}{ll}\text { - } & \text { syndrom Smith-Lemi-Optiz, } \\
\text { - } & \text { syndrom Cogena, } \\
\text { - } & \text { ogniskowa dysplazja korowa, } \\
\text { - } & \text { niedobory w genach: } A M T, \\
& P E X 7, S Y N E 1, B C K D K\end{array}$ \\
\hline $\begin{array}{l}\text { Autosomalne } \\
\text { recesywne } \\
\text { (odziedziczone) }\end{array}$ & $\Rightarrow$ & $\begin{array}{l}\text { - } \quad \text { syndrom Phelana-McDermida } \\
\text { - } \quad \text { syndrom Timothy'ego, } \\
\text { - } \quad \text { syndrom Cornelii de Lange, } \\
\text { - } \quad \text { zespół delecji 22q11.2, } \\
\text { - } \quad \text { syndrom Potockiego- } \\
\quad \text { Lupskiego, }\end{array}$ \\
\hline $\begin{array}{l}\text { Autosomalne } \\
\text { recesywne } \\
\text { (mutacja de novo) }\end{array}$ & $\rightleftarrows$ & $\begin{array}{l}\text { - } \\
\text { - } \quad \text { neurofibromatoza typu } 1, \\
\text { - } \\
\text { niedobory w genach: } C H D 8, \\
D Y R K 1 A, S C N 2 A, A R I D 1 B, \\
A N K 2, G R I N 2 B, S Y N G A P 1, \\
A D N P, T B R 1, P O G Z, \\
K A T N A L 2\end{array}$ \\
\hline Chromosomu X & $\rightleftarrows \stackrel{\rightleftharpoons}{\rightleftharpoons}$ & 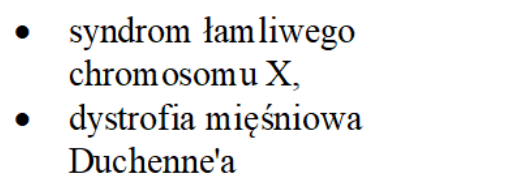 \\
\hline $\begin{array}{c}\text { Ryzyko } \\
\text { addycyjne }\end{array}$ & $\overline{E E} \equiv-2=c$ & - wspólne wariancje \\
\hline
\end{tabular}

- dziedziczenia chromosomu X,

- ryzyka addycyjnego.

Zestawienie wzorców dziedziczenia wraz z głównymi schorzeniami, które te wzorce wywołują zawiera Tabela 1. Wymienione tam syndromy są dość rzadkie i występują zazwyczaj u $1 \%$ pacjentów z ASD, jednakże łącznie szacuje się, że znajdują się one u około $5 \%$ całkowitej populacji osób z omawianym spektrum zaburzeń [5].

Badania nad dziedzicznością zaburzeń ze spektrum autyzmu, szczególnie w przypadku bliźniąt, wykazały, że jest wysokie prawdopodobieństwo odziedziczenia choroby od rodziców [6-8]. Opierano się w głównej mierze na analizie sekwencjonowania całego eksonu (ang. whole-exome sequencing, WES) oraz sekwencjonowaniu całego genomu (ang. whole-genome sequencing, WGS). Dalsze badania genetyczne wykazały, iż rzadkie wariancje proteinowe - polimorfizmy typu CNV (ang. copy number variation) pojawiają się jako nowa mutacja u potomstwa, którego rodzice nie posiadali defektów genetycznych, bądź też jako mutacja zarodkowa w formie SNP (ang. single nucleotide polymorphism) [9-10]. Wariancje genetyczne $\mathrm{w}$ ramach zaburzeń ze spektrum autyzmu w przypadku polimorfizmów typu CNV oraz translokacji przedstawia Tabela 2.

Osoby z zaburzeniami ze spektrum autyzmu posiadały w swoim genomie więcej mutacji niż ich przebadani genetycznie zdrowi krewni. Ponadto ujawniły się, wspomniane powyżej, mutacje de novo, które stanowią także dość istotną grupę czynników występowania omawianych zaburzeń. Najczęściej pojawiającymi się mutacjami tego typu są mutacje w białku helikazy chromodomenowej 8 (CHD8) wiążącym DNA, kinaza regulowana fosforylacją tyrozyny 1A (DYRK1A) oraz delecja lub duplikacja chromosomu 16 (16p11.2) [5]. Niemniej jednak mutacje stricte związane $\mathrm{z}$ zaburzeniami ze spektrum autyzmu są stosunkowo rzadkie [11]. 
Tabela 2. Wariancje genetyczne w ramach zaburzeń ze spektrum autyzmu w przypadku polimorfizmów typu CNV oraz translokacji.

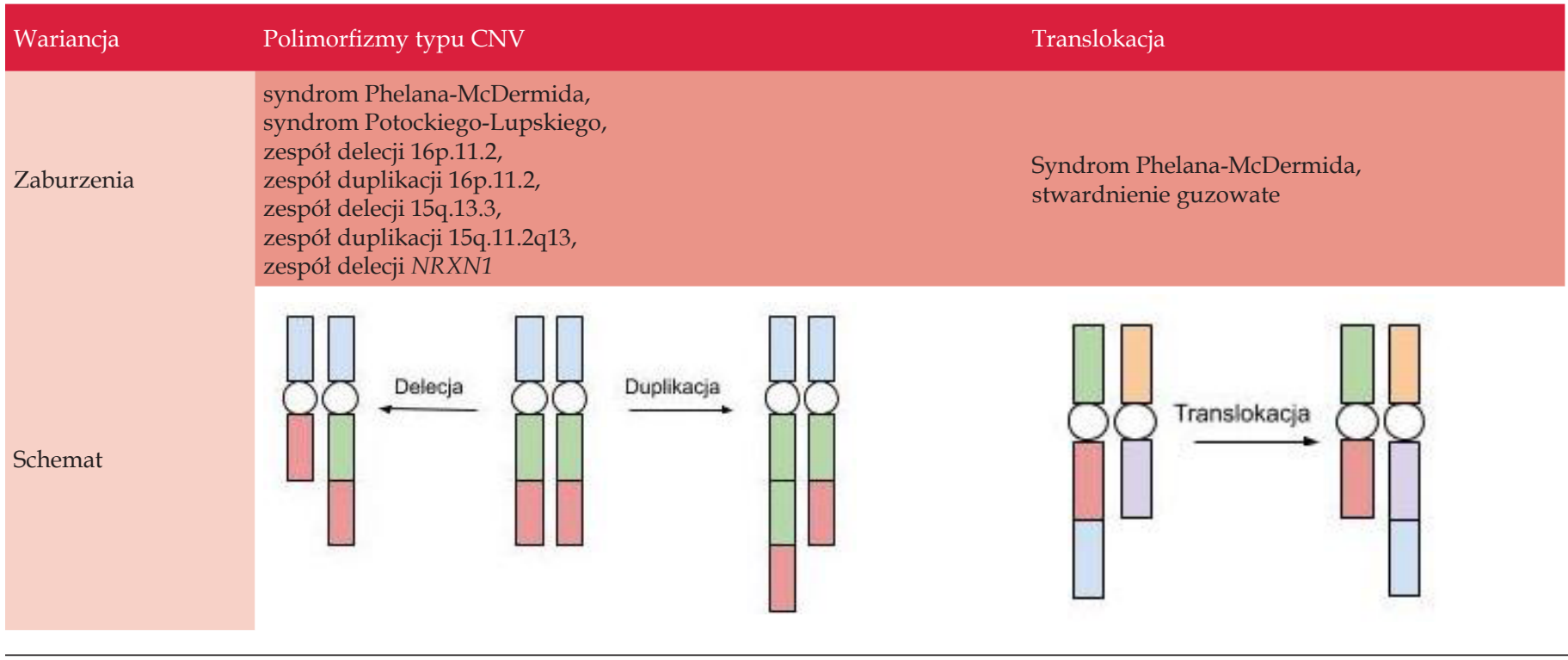

Z tego też powodu występowanie zaburzeń ze spektrum autyzmu spowodowanych mutacjami genetycznymi jest określane z przybliżeniem na podstawie porównania liczby osób chorych do spodziewanej częstotliwości występowania danej grupy mutacji w poszczególnych genach. Procent populacji osób z zaburzeniami ze spektrum autyzmu z podziałem na klasy mutacji przedstawia rycina 1.

W odniesieniu do genetycznej architektury zaburzeń ze spektrum autyzmu wyróżnia się trzy podstawowe modele genetyczne [5]:

Model poligenowy - odnosi się do czynników dziedziczenia choroby w kilku wariancjach, z których każda dodaje małe ryzyko wystąpienia zaburzeń. Potwierdzeniem tego modelu jest częste występowanie zaburzeń ze spektrum u rodzin, w których wykryto wadliwe geny. Ponadto krewni pierwszego stopnia dzieci, u których zdiagnozowano zaburzenia, częściej posiadają powiązany z chorobą fenotyp w porównaniu z populacją ogólną [10]. Występujący u chorych z ASD polimorfizm pojedynczego nukleotydu (SNP), który jest dość rzadko dziedziczony (poniżej 1\% w populacji) wraz $\mathrm{z}$ łącznymi wariantami genetycznymi wskazuje na zwiększoną podatność na zaburzenia ze spektrum autyzmu [12]. Model poligenowy nie pozwolił jednakże na statystycznie istotne wyróżnienie wariancji mogących wywoływać ASD.
Model oligogenowy - odnosi się do czynników dziedziczenia choroby w kilku wariancjach, z których każda dodaje duże ryzyko wystąpienia zaburzeń. W przypadku zaburzeń ze spektrum autyzmu ograniczona liczba mutacji o umiarkowanej do wysokiej penetracji jest wystarczająca do wywołania schorzenia [13].

Model genu głównego - odnosi się do czynników ryzyka wywołanych przez wariancje genetyczne, z których każda dodaje duże ryzyko wystąpienia zaburzeń. Jednakże w tym modelu mutacja jednego genu jest wystarczająca do wystąpienia choroby. W przypadku zaburzeń ze spektrum autyzmu występuje wiele przypadków nowych, nieodziedziczonych mutacji. Jest to szczególnie widoczne przy badaniu rodzeństwa dzieci ze zdiagnozowanymi zaburzeniami, gdzie, pomimo posiadania tych samych rodziców, mutacja nie występuje [14].

\section{NEUROBIOLOGICZNE MODELE I MECHANIZMY ZABURZEŃ ZE SPEKTRUM AUTYZMU}

Rozwój badań genetycznych przełożył się na opracowanie licznych modeli występowania zaburzeń ze spektrum autyzmu u ludzi oraz w organizmach modelowych. W przypadku zaburzeń ze spektrum autyzmu sprawdzanych
Polimorfizm pojedynczego nukleotydu (SNV) de novo - $1,28 \%$

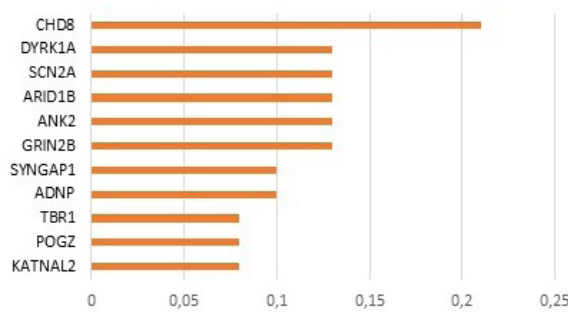

Zmienność liczby kopii (CNV) - 1,28\%

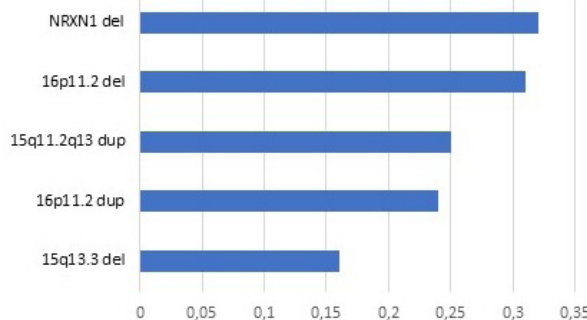

Zespoły genetyczne-3,4\%

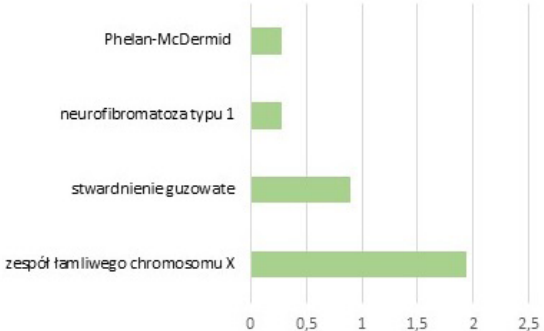

Ryc. 1. Procent populacji osób z zaburzeniami ze spektrum autyzmu z podziałem na klasy mutacji. 
na organizmach modelowych bierze się pod uwagę głównie funkcje molekularne takie jak [5]:

- regulatory transkrypcji dla genu - Tbr1 HT,

- regulatory translacji dla genów - Fmr1 KO, Tsc1 HT, Tsc$1 \mathrm{Cb} \mathrm{KO}, \mathrm{Tsc} 2 \mathrm{HT}$, Pten cKO,

- interakcje pomiędzy neuronami a komórkami glejowymi i grupowanie kationów potasu dla genu - Cntnap2 KO,

- grupowania kationów sodu dla genu - Scn1a KO,

- adhezja synaptyczna dla genów - Nrxn1a KO, Nlgn3 R451C KI, Nlgn3 KO, Nlgn4 KO,

- plastyczność synaptyczna dla genów - Shank2 exon7 KO, Shank2 eksony 6-7 KO, Shank3B KO, Shank3 eksony 4-9 $\mathrm{KO}$, Shank3 HT, Shank3+/ $\Delta \mathrm{C}$.

Dodatkowych możliwości dostarczają badania w zakresie komórek macierzystych poprzez umożliwienie tworzenia ludzkich neuronów. Stwierdzono, że możliwe jest różnicowanie $\mathrm{w}$ funkcjonalne neurony, które mogą modelować fenotypy zaburzeń ze spektrum autyzmu. Dotyczy to głównie embrionalnych komórek macierzystych (hESC), indukowanych pluripotencjalnych komórek macierzystych (hiPSC) i pierwotnych ludzkich nerwowych komórek progenitorowych (phNPC) [5]. Ponadto na podstawie badań nad neuronalnymi komórkami macierzystymi wykazano, że na etiologię zaburzeń ze spektrum autyzmu mogą wpływać nieprawidłowości w neurogenezie, morfogenezie neuronów i funkcjach synaptycznych. Genetyczne modele in vitro zaburzeń ze spektrum autyzmu sugerują, że główne zmiany odnoszą się do genów i inhibitorów [15-17]:

- CHD8 - modelowo reguluje różne zestawy genów związanych z zaburzeniami ze spektrum autyzmu poprzez mechanizmy bezpośrednie i pośrednie.

- SHANK3 - modelowo zmniejszona ekspresja SHANK3 prowadzi do zaburzeń synapsy pobudzającej.

- CACNA1C - modelowo zmniejszona inaktywacja CACNA1C prowadzi do rozregulowania sygnalizacji kationów wapniowych $\mathrm{Ca}^{2+}$, rozregulowanej ekspresji genów i zwiększonej syntezy katecholamin w subpopulacji neuronów korowych.

Większość mechanizmów molekularnych i komórkowych dostarcza dowodów na ich połączenie z zaburzeniami ze spektrum autyzmu. Badania transkryptomiczne na modelach genetycznych wskazują na rozregulowanie określonych procesów molekularnych, które mogą być motorem dla patogenezy. Zalicza się do nich głównie modyfikacje chromatyny czy też składanie RNA [5]. Na poziomie molekularnym na geny związane z etiologią zaburzeń ze spektrum autyzmu oddziałują związki chemiczne odwracające behawioralne lub komórkowe fenotypy. Natomiast w odniesieniu do poziomu komórkowego zmiany prowadzą do przeobrażeń w strukturze mózgu, w tym zakłóceń rozwoju kory mózgowej w okresie płodowym i funkcji synaptycz- nych. W zależności od sprawdzanej przypadłości pierwsze zmiany następują już pomiędzy czwartym a ósmym tygodniem od poczęcia.

W odniesieniu do przyjętej obecnie neurobiologicznej patologii oraz badań nad fenotypami zaburzeń ze spektrum autyzmu, zauważone zostały zmiany we wzroście mózgu. Szczególnie uwidaczniają się:

- zmieniona cytoarchitektura korowa,

- zmieniona łączność komórkowa.

Ich źródło przypisuje się deficytom neurogenezy czy też migracji neuronów i morfogenezy podczas rozwoju płodu [18]. Dodatkowo duży wpływ ma rozregulowanie funkcji synaptycznej, prawdopodobnie $\mathrm{w}$ połączeniu $\mathrm{z}$ reaktywnością mikrogleju i astrocytozy. Wartym wspomnienia jest fakt, iż niektóre leki, jak insulinopodobny czynnik wzrostu czy też roskowityna, zostały z sukcesem użyte do odwrócenia wspomnianych powyżej fenotypów powiązanych $\mathrm{z}$ zaburzeniami ze spektrum autyzmu [19].

\section{CHOROBY GENETYCZNE POWIĄZANE Z ASD}

W przypadku chorób genetycznych, których objawy są łączone z zaburzeniami ze spektrum autyzmu wyróżnia się kilka mechanizmów molekularnych oraz komórkowych połączonych z modelami neurobiologicznymi. W odniesieniu do badań nad zdiagnozowanymi pacjentami oraz na organizmach modelowych wskazuje się jako podstawowe zmiany w korze mózgowej płodu [18]. Zmiany w rozwoju kory mózgowej przedstawiają tylko część nieprawidłowości w tej części mózgu u osób cierpiących na zaburzenia ze spektrum autyzmu. Przyczyny zmian upatruje się zasadniczo w:

- zmniejszonej wielkości neuronów,

- zwiększonej liczbie neuronów,

- ektopii komórek,

- nieprawidłowej orientacji neuronów piramidowych,

- nieregularność laminy,

- zmniejszeniu ilości istoty białej,

- nieprawidłowościach w komórkach dendrytycznych.

Badania na organizmach modelowych wskazują, że nieprawidłowości rozwojowe $\mathrm{w}$ korze mogą być powiązane $\mathrm{z}$ zespołem łamliwego chromosomu $\mathrm{X}$, stwardnieniem guzowatym, czy też bezpośrednio z genami SMARCC2 i CHD8 [18]. Ponadto, zmniejszony rozmiar mózgu u noworodków, po którym następuje jego przerost we wczesnym dzieciństwie jest także uznawany za typowy u pacjentów ze zdiagnozowanymi zaburzeniami ze spektrum autyzmu.

Kolejnym przykładem schorzenia łączonego z zaburzeniami ze spektrum autyzmu jest dysfunkcja synaptyczna. Za podstawowe czynniki ją wywołujące uznaje się mutacje 
w genach kodujących cząsteczki adhezji komórkowej [20]. Ponadto przyczyn choroby dopatruje sie $\mathrm{w}$ problemach $\mathrm{z}$ receptorami GABA. W połączeniu z defektami funkcji glutaminergicznych są uznawane za źródło zmian równowagi procesów pobudzenia i hamowania, prowadzonych do zaburzeń ze spektrum autyzmu. Zaburzona transmisja synaptyczna wpływa dodatkowo na problemy z nauką, zapamiętywaniem oraz funkcjonowaniem społecznym [21].

Innym przykładem są zaburzenia aktywności $\mathrm{w}$ transkrypcji i translacji. W neuronach transkrypcja genów i translacja białek są dynamicznie regulowane przez aktywność neuronów, tworząc przestrzennie lub kontekstowo ograniczoną ekspresję genów w przedziałach subkomórkowych [5]. W ramach przyczyn zaburzeń doszukuje się mutacji MeCP2, CACNA1C, TBR1, TSC1, TSC2, MEF2A, MEF2C. Oparta na aktywności transkrypcja i translacja wpływa na regulacje i stabilność synaptyczną. U osób z zaburzeniami ze spektrum autyzmu uwidacznia się to pod postacią zwiększonej gęstości dendrytycznego kręgosłupa w płatach skroniowych [22]. Zmiany w synapsach prowadzą do zaburzeń behawioralnych.

Ostatnim przytoczonym w niniejszym opracowaniu przykładem są zaburzenia w sygnalizacji neuronów i komórek glejowych oraz zapalanie nerwów. W badaniach osób ze zdiagnozowanymi zaburzeniami ze spektrum autyzmu często występuje aktywowany mikroglej i astrocytoza $\mathrm{w}$ różnych częściach mózgu. Najczęściej ujawniały się nacieki mikrogleju w korze czołowej, przedczołowej i wzrokowej oraz w móżdżku. Astrocytoza natomiast pojawiała się w korze czołowej, ciemieniowej, skroniowej, a także w móżdżku. Geny wzbogacone w aktywowany mikroglej i astrocytozę są regulowane w korze mózgowej u osób cierpiących na zaburzenia ze spektrum autyzmu. Jednakże, do tej pory nie wskazano konkretnych genów stojących za tym schorzeniem. Najczęściej podaje się za przyczynę obniżenie aktywności receptora chemokinowego, który nie jest zmutowany u chorych na zaburzenia ze spektrum autyzmu, a prowadzi do zmniejszenia mikrogleju, zaburzeń synaptycznych oraz powiązanych z nimi zaburzeń behawioralnych [23].

\section{STRATEGIE TERAPEUTYCZNE}

Na obecnym stanie badań wyszukiwane są ścieżki molekularne, które na podstawie modeli systemowych mogą pomóc w stworzeniu odpowiednich strategii terapeutycznych. Hipoteza nierównowagi pobudzenia i hamowania ukazuje modulatory receptorów glutaminergicznych i GABA jako potencjalne strategie, które mogą mieć zastosowanie $\mathrm{w}$ terapii zaburzeń ze spektrum autyzmu. Ponadto badania wykazały, iż roskowityna, antagoniści i agoniści mGluR5, agoniści NMDAR i agoniści GABA $\mathrm{R}$ posiadają różne stopnie skuteczności leczenia przedklinicznego w organizmach modelowych dotyczących łagodzenia deficytów społecznych oraz powtarzalnych zachowań, czy też natręctw [5]. Translacyjne hamowanie translacji przez czynnik eukariotyczny (eIF) 4E, inhibitor interakcji eIF4G (4EGI-1) oraz rapamycynę okazały się skuteczne $\mathrm{w}$ łagodzeniu fenotypów behawioralnych i neuronalnych $\mathrm{w}$ modelach genetycznych zaburzeń ze spektrum autyzmu. Leczenie klenbuterolem i fingolimodem łagodziło także deficyty behawioralne $\mathrm{u}$ organizmów modelowych.

Badania na organizmach modelowych są jednak problematyczne przez pewne braki $\mathrm{w}$ standaryzacji oraz brak testów na ludziach. Uwidacznia to znaczenie dla zrozumienia czynników, które prowadzą do zmiennych wyników badaniach na organizmach modelowych i ludziach. Zachowania społeczne są szczególnie problematyczne, gdyż kontekst środowiskowy i stan badanego są tak ważne, zarówno u ludzi, jak i organizmów modelowych [5]. Dużych możliwości terapeutycznych upatruje się jednak w komórkach mikroglejowych. Ich rola w homeostazie synaptycznej i adaptacyjnej w mózgu może znacząco wpływać na zahamowanie objawów zaburzeń ze spektrum autyzmu. Systemy modelowe oparte na genach zespołu neurorozwojowego wykazują możliwość do odwrócenia pewnych deficytów nawet u dorosłych pacjentów.

\section{PODSUMOWANIE I WNIOSKI}

ASD jest dość powszechnie występującym zaburzeniem neurorozwojowym i stanowi istotny problem dla publicznej opieki zdrowotnej. Pacjenci z ASD stanowią dość heterogenną grupę ze względu na zróżnicowany przebieg zaburzeń i różnorodność objawów. Wpływa to oczywiście znacząco na problematykę samej diagnozy. $Z$ tego też powodu dużych możliwości diagnostycznych oraz terapeutycznych upatruje się w badaniach genetycznych. Jak zwrócono uwagę przy omawianiu genetycznej architektury zaburzeń ze spektrum autyzmu najważniejsze są trzy podstawowe modele dziedziczenia: model poligenowy, model oligogenowy i model genu głównego.

Celem niniejszego artykułu było wykazanie, że genetyczne czynniki etiologiczne stanowią istotną grupę w występowaniu zaburzeń ze spektrum autyzmu. Pomimo dość rozwiniętych możliwości technologicznych oraz ogólnego stanu badań, ASD nadal stanowią zaburzenia, co do których wiele czynników wciąż jest nieznanych. Szczególnych problemów dostarcza niewielka (z punktu widzenia genetyki) próba przeprowadzonych dotychczas badań, przez co bardzo trudno jest ustalić ze znacznym prawdopodobieństwem przyczynowość wariancji genetycznych z omawianą chorobą. Zapewne rozwój i dostępność badań genetycznych znacząco poprawi diagnozowanie zaburzeń ze spektrum autyzmu i umożliwi wprowadzenie odpowiednich terapii.

\section{PIŚMIENNICTWO}

1. American Psychiatric Association (2013) Diagnostic and Statistical Manual of Mental Disorders, fifth edition (DSM-5), American Psychiatric Association, Arlington

2. World Health Organization (2019) The ICD-11 for Mortality and Morbidity Statistics (Version:04/2019), World Health Organization; Geneve https:/ /icd.who.int/browse11/1-m/en

3. Bodfish JW, Symons FJ, Parker DE, Lewis MH(2002) Varieties of Repetitive Behavior in Autism: Comparisons to Mental Retardation. J Autism Dev Disord 30: 237-243 https:/ / doi.org/10.1023/A:1005596502855

4. Elsabbagh M, Divan G, Yun-Joo K, Kim YS, Kauchali S, Marcín C, Montiel-Nava C, Patel V, Paula CS, Wang CH, Yasamy MT, Fombonne E (2012) Global prevalence of autism and other pervasive developmental disorders. Autism Res 5(3): 160-179

5. https://doi.org/10.1002/aur.239 
6. de la Torre-Ubieta L, Won H, Stein JL, Geschwind DH (2016) Advancing the understanding of autism disease mechanisms through genetics. Nat Med 22(4): 345-361 https:/ / doi.org/10.1038/nm.4071

7. Taniai H, Nishiyama T, Miyahci T, Imaeda M, Sumi S (2008) Genetic influences on the board spectrum of autism: Study of proband-ascertained twins. Am J Med Genet 147B(6): 844-849 https://doi. org/10.1002/ajmg.b.30740

8. Rosenberg RE, Law JK, Yenokyan G, McGready J, Kaufmann WE, Law PA (2009) Characterisitics and concordance of autism spectrum disorders among 277 twin pairs. Arch Pediatr Adolesc Med 63(10): 907-914 doi:10.1001/archpediatrics.2009.98

9. Ronald A, Hoekstra RA (2011) Autism spectrum disorders and autistic traits: a decade of new twin studies. Am J Med Genet 156B: 255-274 https://doi.org/10.1002/ajmg.b.31159

10. Sebat J, Lakshmi B, Malhotra D et al. (2007) Strong association of de novo copy number mutations with autism. Science 316: 445-449 DOI: 10.1126/science.1138659

11. Neale BM, Kou Y, Liu L (2012) Patterns and rates of exonic de novo mutations in autism spectrum disorders. Nature 485(7397): 242-245 https://doi.org/10.1038/nature11011

12. Gratten J, Visscher PM, Mowry BJ, Wray NR (2013) Interpreting the role of de novo protein-coding mutations in neuropsychiatric disease. Nat Genet 45(3): 234-238 https:/ / doi.org/10.1038/ng.2555

13. Lee S, Ripke S, Neale B, et al. (2013) Genetic relationship between five psychiatric disorders estimated from genome-wide SNPs. Nat Genet 45(9): 984-994 https:/ / doi.org/10.1038/ng.2711

14. Schaaf CP, Sabo A, Sakai Y, Crosby J, Muzny D, Hawes A, Lewis L, Akbar H, Varghese R, Boerwinkle E, Gibbs RA, Zoghbi HY (2011) Oligogenic heterozygosity in individuals with high-functioning autism spectrum disorder. Hum Mol Genet 20(17): 3366-3375 https://doi. org/10.1093/hmg/ddr243

15. Iossifov I, O'Roak BJ, Sanders SJ (2013) The contribution of de novo coding mutations to autism spectrum disorder. Nature 515(7526): 216 221 https://doi.org/10.1038/nature13908

16. Paşca S Portmann T, Voineagu I, Yazawa M, Shcheglovitov A, Paşca AM, Cord B, Palmer TD, Chikahisa S, Nishino S, Bernstein JA, Hallmayer J, Geschwind DH, Dolmetsch RE (2011) Using iPSC-derived neurons to uncover cellular phenotypes associated with Timothy syndrome. Nat Med 17: 1657-1662 https:/ / doi.org/10.1038/nm.2576
17. Shcheglovitov A, Shcheglovitova O, Yazawa M, Portmann T, Shu R, Sebastiano V, Krawisz A, Froehlich W, Bernstein JA, Hallmayer JF, Dolmetsch RE (2013) SHANK3 and IGF1 restore synaptic deficits in neurons from 22q13 deletion syndrome patients. Nature 503: 267-271 https://doi.org/10.1038/nature12618

18. Sugathan A, Biagioli M, Golzio Ch, Erdin S, Blumenthal I, Manavalan P, Ragavendran A, Brand H, Lucente D, Miles J, Sheridan SD, Stortchevoi A, Kellis M, Haggarty SJ, Katsanis N, Gusella JF, Talkowski ME (2014) CHD8 regulates neurodevelopmental pathways associated with autism spectrum disorder in neural progenitors. Proc Natl Acad Sci U S A 111: 4468-4477 https:/ / doi.org/10.1073/pnas.1405266111

19. Chen JA, Peñagarikano O, Belgard TG, Swarup V, Geschwind $\mathrm{DH}$ (2015) The emerging picture of autism spectrum disorder: genetics and pathology. Annu Rev Pathol 10: 111-144 10.1146/annurev-pathol-012414-040405

20. Zhou J, Blundell J, Ogawa S, Kwon CH, Zhang W, Sinton C, Powell CM, Parada LF. (2009) Pharmacological Inhibition of mTORC1 Suppresses Anatomical, Cellular, and Behavioral Abnormalities in Neural-Specific Pten Knock-Out Mice. J Neurosci 29(6): 1773-1783 https:/ / doi.org/10.1523/JNEUROSCI.5685-08.2009

21. De Rubeis S, He X, Goldberg AP et al. (2014) Synaptic, transcriptional and chromatin genes disrupted in autism. Nature 515(7526): 209-215

22. Yizhar O, Fenno LE, Prigge M, Schneider F, Davidson TJ, O'Shea DJ, Sohal VS, Goshen I, Finkelstein J, Paz JT, Stehfest K, Fudim R, Ramakrishnan C, Huguenard JR, Hegemann P, Deisseroth K. (2011) Neocortical excitation/inhibition balance in information processing and social dysfunction. Nature 477(7363): 171-178 https:/ / doi. org/10.1038/nature10360

23. Hutsler JJ, Zhang H (2010) Increased dendritic spine densities on cortical projection neurons in autism spectrum disorders. Brain Res 1309: 83-94 https://doi.org/10.1016/j.brainres.2009.09.120

24. Zhan Y, Paolicelli RC, Sforazzini F, Weinhard L, Bolasco G, Pagani F, Vyssotski AL, Bifone A, Gozzi A, Ragozzino D, Gross CT (2014) Deficient neuron-microglia signaling results in impaired functional brain connectivity and social behavior. Nat Neurosci 17(3): 400-406 https:/ / doi.org/10.1038/nn.3641

\section{Genetic factors in Autism Spectrum Disorders (ASD)}

\section{Sylwia Trambacz-Oleszak ${ }^{\varpi}$, Tetiana Nosulia}

Institute of Human Biology and Evolution, Faculty of Biology, Adam Mickiewicz University in Poznan, Poznań, Poland

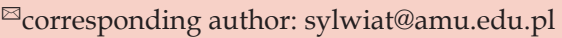

Key words: autism, ASD, genetic factors, genetic mutations, modes of inheritance

\section{ABSTRACT}

Autism spectrum disorder (ASD) is common early neurodevelopmental disorder characterized by a varied trajectory and symptoms which affects diagnosis and therapy. For this reason, great diagnostic and therapeutic possibilities are seen in genetic studies. The aim of this review is to discuss the genetic architecture of ASD and possible therapeutic strategies.The patterns of ASD inheritance are discussed, genetic variations (including CNV polymorphisms) and the percentage of the ASD patients divided into specific classes of genetic mutations are indicated. The paper shows the most important three basic models of inheritance: polygenic, oligogenic and main gene. Molecular and cellular mechanisms linked to neurobiological models of ASD are also presented. Genetic research confirms the diversity of genetic factors involved in the ASD formation. Model systems based on the genes of the neurodevelopmental syndrome show the ability to reverse some deficits in adult patients. 